\title{
ADDITIONS TO THE MANITOBA BIRD LIST (1985-1990)
}

\section{RUDOLPH F. KOES, 135 Rossmere Crescent, Winnipeg, Manitoba. R2K OG1}

Since 1984, when the last compilation of species new to the known Manitoba avifauna was completed, several species have been added to the provincial list. ${ }^{26}$ In some cases these species had never before been reported in the province, while in other instances documentation was received which allowed species to be moved from the hypothetical list to the confirmed list. Confirmed records are those for which material evidence in the form of a specimen, photograph or sound recording exists, or well-documented sight records made by two or more competent observers.

The following is a list of 20 species new to the province. All records were reviewed by the Manitoba Ornithological Records Committee (MORC) (presently H.W.R. Copland, Chair; R.F. Koes, R.W. Nero, and P. Taylor). Seven of these (Yellow-billed Loon, Glossy Ibis, White-faced Ibis, Black-legged Kittiwake, Blue-grey Gnatcatcher, Northern Wheatear and Brewer's Sparrow) were previously on the hypothetical list and have since been confirmed. Six confirmed species had not been reported prior to 1985; one is the result of a "split," while another six species were added to the hypothetical list. All accepted species are indicated by an asterisk (*). The author would appreciate being informed of any missing, incomplete or incorrect information in this list.

* Yellow-billed Loon. All observations in Manitoba of this large loon have occurred at Churchill. A bird sighted on 19 June 1981 by B. Aike, Kenn Kaufman, Doug McRae, and others has since been accepted by MORC. ${ }^{10}$ On 28 May 1985, Michel Masse and Dwight Cargill saw one at the mouth of the Churchill River, and two there on 29 May. These dates were incorrectly reported as 3 and 4 June in American Birds. ${ }^{20}$ Sightings on 26 June 1980 and 9 June 1987 lack documentation. ${ }^{9,14}$

Considering the proximity of the Yellow-billed Loon's breeding range to Manitoba, it is perhaps surprising that observations are not more frequent. Godfrey explains however that "Migration ... apparently is mostly coastwise around northern Alaska. ..." and not south through Manitoba. ${ }^{8}$

* Clark's Grebe. The occurrence of Clark's Grebe was known in the 19th century. Ernest Thompson Seton makes mention of it in The Birds of Manitoba, published in $1891 .^{38}$ Only in 1985, though, has it been restored to full species status. ${ }^{2}$

Gary Nuechterlein noted about five birds, plus several hybrids, over a period of seven years during his studies at Delta Marsh (pers. comm.). This was before the bird received species status.

The first confirmed record of the Clark's Grebe since the split was an adult at Natalie Lake near Seven Sisters Falls on 3 May 1986, seen by a Manitoba Naturalists Society birding party. ${ }^{12}$ Nuechterlein observed a mated pair at Delta during mid-June 1986 . $^{7}$ During that same summer Ken De Smet found the first nest for Manitoba - and Canada - at Pelican Lake. ${ }^{7}$ Since that time the species has been reported annually in the province, although it is clearly greatly outnumbered here by Western Grebes. The most interesting 
report involved six birds seen with 25 Western Grebes at Clear Lake, Riding Mountain National Park, on 29 May 1990 by Dan Weedon, Stu Tingely, and a Wings birding tour (Manitoba Bird Record Card system).

* Northern Gannet. A Northern Gannet was one of the first birds seen by Simon Perkins and a Massachusetts Audubon Society tour group during a 1989 visit to Cape Merry, Churchill. ${ }^{18}$ Field notes and a sketch made at the time - the morning of 17 June - clearly identify it as an adult. Eight other observers shared what must have been a highlight of the trip. The visit of this East Coast bird to the southern reaches of Hudson Bay was not unprecedented; one was seen on 29 October 1981 near Moosonee on James Bay, Ontario. ${ }^{19}$

* Glossy Ibis. Of the half dozen or so ibis sightings in the province up to 1989 , at least two were reputed to have involved the Glossy Ibis. Neither one was well described; a 1934 report is particularly suspect. ${ }^{33}$

On 24 May 1989, Martin Siepman discovered an adult in the southeast corner of Oak Hammock Marsh Wildlife Management Area (WMA). The bird was last seen on 26 May in the same general area of the marsh. ${ }^{17}$ No photographs were obtained, but at least three observers saw it well enough to separate it from the similar White-faced Ibis. Diagnostic green legs with red "knees" were noted, as well as the distinctive face pattern.

* White-faced Ibis. From 2 to 6 May 1990 an adult was present at the north end of Oak Hammock Marsh WMA. It proved more cooperative than the Glossy Ibis mentioned above, and, after its discovery by Bill May, was seen at close range by most observers who looked for it. Several diagnostic photographs were taken; one appeared in American Birds. ${ }^{3,28}$
Sightings at St. Ambroise on 18 and 31 May 1975 and at Oak Hammock Marsh WMA on 26 May 1975 and 6 August 1977 were ascribed to this species, but none fitted MORC's criteria for confirmed status. ${ }^{36}$

Mute Swan. On a number of $o c$ casions Mute Swans have been seen in the wild in Manitoba. One such bird was seen - but not counted! - by Dennis Fast, Gord Grieef, Peter Taylor, and the author during a "Big Day" effort on 27 May 1989 at Oak Hammock Marsh WMA. It was still present on 31 May (MORC files). A check with the few possible sources within the province revealed it had not escaped from a local collection. It is possible that the bird had migrated with Tundra Swans from the Great Lakes, where a feral population of Mute Swans exists, or that it originated at a collection in one of the nearby states. Mute Swans that have reached Manitoba at other times probably arrived here in a similar fashion.

While the 1989 sighting was well documented and was accepted by MORC, the status of the species as a true vagrant in Manitoba is still much in question.

Black Rail. A bird which was flushed from tall grass and was seen briefly as it fluttered away from I.M. Gardner at Oak Hammock Marsh WMA, on 22 May 1989, may have been a Black Rail. ${ }^{17}$ Few details could be noted during the short observation period, precluding positive identification. The presence of this diminutive rail in Manitoba must remain hypothetical.

Black-tailed Gull. While on a survey trip aboard a fishing vessel studying colonial water birds in the summer of 1987, Richard Knapton discovered what he subsequently believed to be a Blacktailed Gull. The gull was seen for about 15 minutes on the afternoon of 2 June, as it followed the vessel near Coleman 
Island, Sagemace Bay, Lake Winnipegosis. Detailed notes were taken and the account was subsequently published in Blue Jay. Unfortunately, its presence could not be confirmed by other birders. $^{25}$

This eastern Asiatic species had previously been reported from the western Aleutians, southern California, and Maryland, but not from Canada. ${ }^{25}$

* Black-legged Kittiwake. During a 9 October 1986 MORC meeting an 18 July observation of a Black-legged Kittiwake at Churchill was accepted as confirmed. ${ }^{11}$ Details are still lacking on a 1980 sighting, which also took place at Churchill. ${ }^{9}$ It is likely that more kittiwakes will turn up in Manitoba; the first inland sighting in the province is long overdue.

Greater Roadrunner. Bill Thiessen reported seeing a roadrunner run across his property near Poplar Point on 22 April 1989. ${ }^{17}$ His verbal description of the event was fairly convincing. A subsequent extensive search of the area by numerous birders failed to locate the bird. If the identification was indeed correct, it undoubtedly involved an escaped pet, as roadrunners are sedentary and do not occur closer to Manitoba than southern Kansas. ${ }^{1,6}$

* Scrub Jay. Manitoba's first - and Canada's second - record came from Fisher Branch in the Interlake area about $115 \mathrm{~km}$ north of Winnipeg. ${ }^{17,23}$ From about 6 December 1988 until about 8 February 1989 a Scrub Jay visited the feeder of Dianne Gard of that community. Photographs taken by conservation officer Gerry Rosset clearly identify it as belonging to one of the interior races, which range as far north as southern Idaho and Wyoming. ${ }^{1}$ By the time the Manitoba birding community got word of the jay, it had long since disappeared and the birders were much chagrined not to be able to add the species to their lists.

* Blue-grey Gnatcatcher. Since the status of the Blue-grey Gnatcatcher in Manitoba was described in 1990, additional written documentation on the 31 August 1982 Kleefleld sighting has enabled MORC to include the species on the Manitoba list. ${ }^{26}$

Blue-grey Gnatcatchers have recently been reported for the first time from Saskatchewan, while North Dakota had its fifth record in the spring of $1990 .^{30,32}$

* Northern Wheatear. Although wheatears have been reported at least ten times in Manitoba since 1968, no properly documented sightings by two or more experienced observers were known to us. ${ }^{5,16,34,39}$ Birds seen at Churchill in May 1988 were reported as the first confirmed records for the Prairie Province region in American Birds, but, again, we have not seen the evidence. ${ }^{15}$

Recently MORC received acceptable documentation on two observations made in 1982 and 1990. A Northern Wheatear seen at Bird Cove near Churchill on 24 June 1982 by Warren Bielenberg and Richard Verch was well described and sketched. Another was located 9 June 1990 by a tour group led by Kim Eckert, also at Churchill. It was believed to have been a first spring male of the western race and it was photographed by Bob Williams of Florida (copy in MORC files).

Yellow Wagtail. The La Perouse Bay area of northern Manitoba is best known for its large Snow Goose colony. While researchers and students at the site have found a number of rarities over the years, the most unusual vagrant to date must have been a Yellow Wagtail, seen on 2 May 1988 by R.J. Hughes and M.D. Carter. Unfortunately, their written report was not detailed enough to positively establish the identity of the bird. 
* Blue-winged Warbler. Until recently Manitoba had lagged behind Saskatchewan in adding a number of southeastern wood warblers to its avifauna. In the last four years we have fortunately caught up and are now on more equal footing.

Keith Hobson found a misguided Blue-winged Warbler at Delta on 7 November 1987, well after all warblers have usually left for warmer climes. It foraged on or near the leafy forest floor; a brilliant spark in subdued surroundings. A number of birders managed to see it on 8 November. Hobson also photographed it. ${ }^{2}$

* Yellow-throated Warbler. The Delta Marsh beach ridge at the south end of Lake Manitoba has produced more than its share of rare bird sightings. This is partially explained by its location, which concentrates migrants along the lakeshore, but is also due to the presence of knowledgeable staff and students at its two research facilities, the University of Manitoba Marsh Field Station and the Delta Waterfowl Research Station. The first Blue-winged, Yellow-throated and Prothonotary Warblers for the province were seen in this area.

On 23 May 1987 Roger Titman discovered a Yellow-throated Warbler in beach-ridge forest just east of the field station. It was seen the same day by Spencer Sealy and Percy N. Hebert, but subsequent searches failed to locate it. ${ }^{13}$ The author remembers dragging his family out half a day after completing a gruelling - but successful - "Big Day" to search for the vagrant. We did not find the warbler, but a Glaucous Gull catching insects on the wing with Franklin's Gulls was a fine consolation.

A more cooperative bird was present from 20 to 25 June 1990 at the Oak Lake resort, where it sang from mature oak/ elm woods. It had been found by David Hatch and Martin Siepman and was seen 49(4). December 1991 by numerous birders. Gord Grieef obtained a few diagnostic photographs. ${ }^{29}$

* Prairie Warbler. The second of two rare warblers found by David Hatch in the summer of 1990, a Prairie Warbler, made the second-growth of an old burn in the boreal forest at Whirlpool Lake, Riding Mountain National Park, its home from 3 July to at least 10 July. Peter Taylor took a number of excellent photographs. ${ }^{4,29}$

While the warbler initially sang vigorously, it was less enthusiastic later on. On at least two dates it was heard to sing perfect - albeit muted - renditions of the Black-throated Warbler's song, and on one of these occasions (10 July) it was accompanied for some time by a female of that species.

This represents the first record for the species from the Prairie Provinces.

Prothonotary Warbler. Another one of the spectacular wood warblers first found in Manitoba at Delta is the Prothonotary Warbler. On the evening of 17 May 1989 Spencer Sealy saw a bird immediately east of the University of Manitoba Field Station. Others could not find it in the early moming of 18 May. MORC is awaiting written details on this sighting. ${ }^{17}$

The second observation involved a male seen on 31 July 1990 at Birch Point on Buffalo Bay, Lake of the Woods, in the extreme southeast corner of the province. Martin Siepman was the lucky observer. $^{29}$

* Brewer's Sparrow. While conducting a birding tour in the famed Douglas Marsh near Brandon on 2 July 1988, Calvin Cuthbert heard an unfamiliar song. The Douglas Marsh is renowned for its Yellow Rails and Le Conte's Sparrows, but for the next few days these were all but forgotten and a soggy path was beaten to the songster's 
territory by many members of Manitoba's birding fraternity. The bird was a Brewer's Sparrow, one of the plainest birds of the plains; a sparrow of western sagebrush with a pleasant song, reminiscent at times of a Vesper Sparrow or a canary. It was last noted on 10 July, not 7 July as reported in American Birds. ${ }^{16}$

An unconfirmed 1982 sighting at Churchill has been discussed previously. ${ }^{26}$

* Eurasian Tree Sparrow. From 2 November 1986 to 22 January 1991 a Eurasian Tree Sparrow made the yard of Helen and James Owen in St. Francois Xavier, just west of Winnipeg, its home..$^{21,27,31}$ It arrived on the eve of a wicked fall blizzard, found a wellstocked feeder and stayed for the next four years. In the summer of 1989 it was observed feeding young sparrows, whose ancestry was not established. During summer 1990 and the following winter three obvious Eurasian Tree Sparrow/House Sparrow Hybrids were seen and photographed. ${ }^{31}$ Further, Anthony Lang, a University of Toronto $\mathrm{Ph}$. D. candidate studying the species, banded all three hybrids in the spring of 1991.

As there was no evidence to support prior captivity or man-assisted transport of the parent bird, it was accepted as a first Manitoba record. Similarly, in the summer of 1990 the species was added to the Minnesota list. ${ }^{24,37}$

A number of other species, including Swan Goose and Egyptian Goose, have been reported in the wild recently, but as these birds are not native to North America and are commonly kept in collections, they were considered to be escapees. Finally, the sighting of an Acadian Flycatcher on 10 June 1985 has been rejected by MORC.

Bird record committees continue to face difficulties in their task. Roberson recently wrote an informative article on such committee and he stated: "The majority of U.S. committees listed 'lack of observer cooperation' and 'lack of adequate documentation' as their most significant concerns." 35 Our situation is certainly no different; even some of our most active birders rarely or never provide documentation of their sightings. Observers visiting Churchill could facilitate MORC's job, as many observations of rarities in the area remain undocumented. Please forward reports of sightings to MORC, c/o Herb Copland, Manitoba Museum of Man and Nature, 190 Rupert Avenue, Winnipeg, Manitoba, R3B 0N2. As an added incentive, it should be mentioned that the Manitoba Avian Research Committee is presently working on The Birds of Manitoba and would like to include as many valid records as possible.

\section{Acknowledgements}

Herbert W. R. Copland has been most helpful in providing information about records in the Manitoba Museum of Man and Nature. Peter Taylor's comments and suggestions have greatly improved the manuscript. Many thanks also go to the observers who have taken the time to provide us with documentation.

1. AMERICAN ORNITHOLOGISTS' UNION. 1983. American Omithologists's Union check-list of North American birds. Sixth edition, American Omithologists' Union. 877 pp.

2. 1985. Thirty-fifth supplement to the American Omithologists's Union checklist of North American birds. Auk 102:680-686.

3. ANONYMOUS. 1990. Regional Pictorial highlights spring 1990. Am. Birds 44:378380 .

4. - 1990. Pictorial highlights summer 1990. Am. Birds 44:1210-1213.

5. CUMMING, E.E. 1988. Northern Wheatears sighted in Duck Mountain Provincial Park, Manitoba. Blue Jay 46:84-85.

6. DESANTE, D. and P. PYLE. 1986 
Distributional checklist of North American birds. Volume 1: United States and Canada. Artemesia Press, Lee Vining, CA. 442 pp.

7. DE SMET, K.D. 1987. First nesting record and status of the Clark's Grebe in Canada. Blue Jay 45:101-105.

8. GODFREY, W.E. 1986. The birds of Canada. revised edition. Natl. Mus, Nat. Sci., Ottawa. 595 pp.

9. GOLLOP, J.B. 1980. The nesting season: Prairie Provinces region. Am. Birds 34:905-906.

10. 1981. The nesting season: Prairie Provinces region. Am. Birds 35:950-952.

11. 1 1982. The nesting season: Prairie Provinces region. Am. Birds 36:988-990.

12. 1986 . The spring migration: Prairie Provinces region. Am. Birds 40:487-488.

13. -1987 . The spring migration: Prairie Provinces region. Am. Birds 40:448-450.

14. - 1987. The nesting season: Prairie Provinces region. Am. Birds 41:14511453.

15. 1988. The spring migration: Prairie Provinces region. Am. Birds 42:450-451.

16. - 1988. The nesting season: Prairie Provinces region. Am. Birds 42:13041305.

17. 1989 . The spring migration: Prairie Provinces region. Am. Birds 43:495-497.

18. 1 1989. The nesting season: Prairie Provinces region. Am. Birds 43:13301332.

19.GOODWIN, C.E. 1982. The Autumn migration: Ontario region. Am. Birds 36:171-174.

20.HARRIS, W.C. 1985. The nesting season: Prairie Provinces region. Am. Birds 39:927-928.

21. 1987. The autumn migration: Prairie Provinces region. Am. Birds 41:104-106.

22. HOBSON, K.A. 1988. First record of the Blue-winged Warbler in Manitoba. Blue Jay 46:86-87.

23.HUNN, E.S. and P.W. MATTOCKS. 1982. The autumn migration: Nonhern Pacific Coast region. Am. Birds 36:208211.
24.JANSSEN, R.B. and P. SVINGEN. 1990. A Eurasian Tree Sparrow in Minnesota. Loon 62:175-177.

25. KNAPTON, R.W. 1990. Black-tailed Gull in southern Manitoba. Blue Jay 48:37-38.

26. KOES, R.F. 1985. Additions to the Manitoba bird list (1975-1984). Blue Jay 43:224-231.

27. - 1988. Eurasian Tree Sparrow in Manitoba. Blue Jay 46:34-35.

28.KOES, R.F. and P. TAYLOR. 1990. The spring season: Prairie Provinces region. Am. Birds 44:445-447.

29. - 1990. The nesting season: Prairie Provinces region. Am. Birds 44: 11481149.

30. - 1991. The autumn migration: Prairie Provinces region. Am. Birds 45:118-120.

31. - 1991. The winter season: Prairie Provinces region. Am. Birds 45:287-288.

32. LAMBETH, D.O. 1990. The spring season: Northern Great Plains region. Am. Birds 44:447-450.

33. LAWRENCE, A.G. 1934. Tropical bird at St. Laurent? Chickadee Notes 707, Winnipeg Free Press, 12 October 1934.

34. LITTLEFIELD, C.D. 1970. Wheatear observations near Fort Churchill, Manitoba. Can. Field-Nat. 84:404-405.

35. ROBERSON, D. 1990. North American bird records committees. Birding 22:276285.

36.SERR, E.M. 1975. The spring migration: Northern Great Plains. Am. Birds 29: 867 870.

37. TESSEN, D.D. 1990. The nesting season: Westem Great Lakes region. Am. Birds 44: 1135-1137.

38. THOMPSON, E.E. 1891. The birds of Manitoba. Proceedings U.S. National Museum 13:457-643.

39. WEDGWOOD, J. 1982. The spring migration: Prairie Provinces region. Am. Birds 36:864-866. 